\title{
LOS LÍMITES A LA REFORMA CONSTITUCIONAL ANTE PROPUESTAS MÁS PROPIAS DE UNA REVOLUCIÓN
}

\author{
ENRIQUE BELDA PÉREZ-PEDRERO \\ Profesor Titular de Derecho Constitucional \\ Universidad de Castilla La Mancha
}

SUMARIO

I. ¿Límites materiales implícitos?

II. Una descripción de los límites a la reforma

En las dos últimas ocasiones que se ha planteado una propuesta de reforma de la Constitución española de 1978, (de las que se ha culminado solo la segunda, sobre el art. 135); han surgido numerosas voces que aprovechan la circunstancia para intentar ampliar el objeto de iniciativa propuesto por sus impulsores. Son preocupantes las propuestas de ciertas minorías cuyo contenido resulta contrario al pacto constituyente de 1978, incluyendo como posibles objetos de reforma la supresión de La Corona o el derecho a la autodeterminación de nacionalidades y regiones.

\section{I. ¿LÍMITES MATERIALES IMPLÍCITOS?}

El estudio de los límites jurídico-constitucionales ante una propuesta de reforma en los términos «excesivos» que ocasionalmente barajan algunas minorías, se presenta como el tema clave y de mayor importancia práctica de un proceso de cambio en la norma fundamental.

Lo más complejo de establecer cualquier línea en un campo como la ciencia jurídi$\mathrm{ca}$, es partir de las diferentes interpretaciones posibles de la misma realidad. En el derecho constitucional además, la invasión de ciertas consideraciones de la ideología y los valores, es relevante para el operador jurídico, en tanto forman parte del articulado constitucional (valores del art. 1 CE, la dignidad de la persona del art. 10 CE, todo el Título I, buena parte de las instituciones respaldadas con una garantía, que conforman la naturaleza del Estado, etc.). Esta contaminación de las percepciones sociales y políticas se despliega con toda su fuerza en la reforma constitucional, ya que la propia esencia de esta 
institución del derecho, consiste en la adecuación de la norma a la realidad. ¿Cómo evitar los elementos extrajurídicos ante un proceso de búsqueda de los límites de la reforma, si estos existieren? ¿Se deben evitar?

Los poderes constituidos, que realizan sus funciones bajo el mandato de una norma constitucional, derivan su fuerza de un código de comportamiento concreto que se otorgaron en su día, que aunque pueda evolucionar o ser reinterpretado, y desde luego reformado, constituye por si mismo un modo de organización perfilado y completo. Esta estructura puede ser demolida para construir otra distinta, pero no subvertirse alterando sus bases más sustanciales. Esos pilares básicos, nacidos del proceso constituyente son derecho positivo reflejado en la norma constitucional, y desde una lectura estrictamente jurídica de toda ella se puede advertir (probablemente en algunos casos, con problemas) cuándo sostienen la arquitectura constitucional, y cuándo pueden ser removidos en atención a la necesidad adaptativa que exige la institución de la reforma, que a su vez es otro de esos pilares del edificio normativo.

La Constitución tiene por tanto una ideología juridificada que ha de estimarse con tanta fuerza como una lectura aislada y literal de sus preceptos constitucionales sobre la reforma. Si en ellos, como ocurre en la Constitución española de 1978, no se mencionan expresamente elementos intangibles excluidos de una reforma por cualesquiera causas, habrá que volver la vista hacia el resto del articulado que forma el sistema completo, para descubrir el «alma» de esa norma, que por ser constitución y a diferencia de otras, siempre tiene.

Llegados a este punto, lo que cabe preguntarse es si una sociedad puede alterar ese código de conducta establecido por el constituyente. Evidentemente que sí, en especial si el sistema lo permite, como sucede en España. Pero ha de decidir si lo hace para readaptarlo, manteniendo la esencia del mismo, o si lo que procede es una cambio de mayor envergadura. La representación política tiene entonces la palabra, o incluso si la misma estuviera viciada por cualquier motivo, el propio ciudadano, por otros medios podría expresarse. Así, lo que en principio parece como un problema jurídico de incierta solución: hasta qué extremo el cambio es reforma, y a partir de qué hito se está subvirtiendo el espíritu constituyente; también puede plantearse extramuros del derecho, entendiendo que la constitución es una norma que regula organización y convivencia, y de no conseguir estos objetivos, puede cambiarse por otra. Puede que la solución jurídica no sea lejana: ¿Por qué no reemplazar la constitución por otra?

Evidentemente que esos no son los términos del problema de la última reforma que se presenta en España y en algunos países de su entorno, ya que lo que la sociedad pretende, o al menos expresa actualmente a través de los poderes constituidos (el pueblo como electorado, el parlamento), es el reajuste y la renovación de las bases que otras generaciones más o menos cercanas, establecieron en el pacto constitucional fundacional. Pero por lo que afecta a los temas expresados por ciertas minorías nacionalistas o antisistema, la cuestión básica es interrogarse sobre si hay límites para reformar nuestra actual constitución y cuáles son. De todo lo anteriormente apuntado se deduce nuestra respuesta: parece que los hay, implícitos, al margen de los que expresamente marque la Constitución, porque la reforma por su propia naturaleza es constitucional, con lo que ha de entenderse como sistema completo, y ante todo, porque la reforma es una de tantas posibilidades del texto constitucional, que nada sería para un Estado ni para la sociedad, sin la fuente que habilita su funcionamiento, la propia norma a reformar. Su naturaleza es 
esencialmente limitada y sometida. Por ello, reforma, desde cualquier punto de vista (teoría de la reforma constitucional, acepción de significado, antecedentes históricos, etc.) es cambio limitado. La respuesta a cuáles son esos límites, desde una visión racional y estrictamente positiva, los marcan también las propias constituciones, que unas veces establecen limites de procedimiento, otros de fondo u otros mencionan la posibilidad de reforma sin más acompañamiento. Pero evidentemente, la presentación de unas normas constitucionales de reforma sin cláusulas de intangibilidad o protecciones institucionales expresas, no convierte a las mismas en normas que habilitan la revolución, ya que para ello, no hacen falta normas.

Aláez Corral, en uno de sus trabajos sobre la materia resume con las siguientes palabras la capacidad de reforma total de nuestra Constitución, pero siempre que se esté dispuesto a hacerlo a cualquier precio: «(... la propia Constitución española de 1978, al prever expresamente la posibilidad de una reforma total y, en particular, la posibilidad de reforma de la esencia del principio estructural de Estado democrático, ha querido convertir en jurídicamente lícita, aunque pudiera no ser democrática, la operación por la que el Estado democrático se transforma en otro más o menos autocrático. )» ${ }^{1}$. El campo de juego de la teoría de reforma de la constitución es siempre la pervivencia del principio democrático, como muy extensamente volvió a recordar Díaz Ricci ${ }^{2}$ por lo cual es una realidad limitativa, siempre presente, que el proceso de reforma puede llevar hacia cualquier nuevo marco institucional y de derechos, pero de corte democrático. El límite de actuación es evidente, sin necesidad de más explicaciones, porque nunca será reforma la utilización del procedimiento destinado a ello para finalizar un régimen de libertades y participación.

Lo que se plantea en España es si el constituyente español permitió que la reforma se pudiera convertir en una especie de revolución, y habilitó, a través del art. $168 \mathrm{CE}$, que una vez sufrido el complejo procedimiento agravado de reforma, el texto resultante, por lejano que pareciese de la voluntad del poder constituyente, pudiese seguir ostentando el título de «Constitución española de 1978». La respuesta es afirmativa, pero el problema suscitado es meramente teórico porque la sociedad se regiría en su caso por la nueva norma (denominada como Constitución española de 1978 reformada) o por otra (denominada a partir de su nueva fecha). Digamos que el asunto no iría más allá de la nominación histórica.

Sin embargo, la decisión suprema del constituyente que permite estar abierta a cambios en el futuro a través de las normas de reforma, carece de la capacidad de prolongarse artificialmente cuando se presenta otra realidad fundacional nueva. Así, se estaría ante una circunstancia totalmente distinta que exigiría cambiar las reglas de convivencia. El periodo de vigencia constitucional es una unidad histórica que va más allá de la suma del tiempo en el que se aplica, y define un estado de las relaciones sociales e institucionales en cada país. Por ello, la mayor parte de la doctrina nacional, siguiendo las pautas mar-

1 ALÁEZ CORRAL, B., «La reforma constitucional como motor de las transformaciones actuales del Estado español», En Derecho constitucional para el Siglo XXI. Actas del VIII Congreso de Derecho Constitucional, Pérez Royo et alii (eds.), págs. 465 a 488, Thomson-Aranzadi, Cizur Menor, Navarra, 2006. Cita en pág. 475, siguiendo a BASTIDA FREIJEDO, F.J., «La soberanía borrosa: la democracia», Fundamentos, n 1, 1998, págs. 390 y ss.

2 DÍAZ RICCI, Sergio M., Teoría de la reforma constitucional, UNAM-UCM-Ediar, Buenos Aires, 2004, págs. 303 a 338 . 
cadas desde décadas en la apreciación de la teoría de la reforma, opta, como dijimos en páginas anteriores, por entender que el poder de reforma es para modificar la constitución, no para destruirla ${ }^{3}$. Carece de sentido que el propio constituyente habilitase un mecanismo de autodestrucción en lugar de uno de adaptación.

El debate por ello, ha de circunscribirse a los siguientes términos: se trata de valorar si la actual Constitución española tiene límites implícitos, más que de responder si es posible su reforma, hasta el punto de terminar con el estado de cosas que consagra, sin reparar en más consideraciones, lo que desde luego siempre será posible. Sucede que esto último no podría denominarse reforma sino cambio constitucional ${ }^{4}$. Por ello, la Constitución de 1978 permite su cambio absoluto, pero la reforma como tal habrá de considerar, en principio, la posibilidad de ciertas limitaciones.

La doctrina española a la que nos venimos refiriendo, sitúa el estudio de los límites de la reforma como clave de buena parte de sus conclusiones, siendo especialmente reseñables los trabajos de quienes se esfuerzan por encauzar la detección de los mismos a partir de criterios estrictamente jurídicos 5 . Se critica, por ello con acierto, que la parte articulada que la Constitución de 1978 dedica a su propia reforma, carezca de referencia expresas a institutos o valores intangibles: la superlegalidad formal demanda acompañar los compromisos con algunos rasgos sustanciales del sistema ${ }^{6}$. Al final, sin referencias axiológicas que respalden el porqué de la reserva de ciertas materias en el art. $168 \mathrm{CE}$, el poder constituyente y el de revisión, absolutamente libre, se situarían en el mismo plano. Las prohibiciones o límites son meramente temporales (a través del art. $169 \mathrm{CE}$, que prohíbe el inicio de la reforma durante la vigencia de los estados del art. 116 CE o en situación de guerra). Por ello, literalmente el poder constituyente se equipara por el Título $\mathrm{X}$ al poder de reforma ${ }^{7}$.

Con Ruipérez pueden recapitularse los rasgos esenciales que fundamentarían la existencia de unos posibles límites, intentando discutir la mera aplicación literal del Título X CE y con ello la permisibilidad absoluta de una reforma ilimitada: siguiendo a Schmitt, la revisión constitucional es una competencia limitada por tratarse de una fa-

3 VEGA GARCÍA, P. de La reforma constitucional y la problemática del poder constituyente

Tecnos, Madrid, 1985. pág. 238.

4 En terminología de Schmitt, estaríamos o bien ante una destrucción de la constitución o bien ante una supresión, si se considerase, cuestión más que difícil, que el poder constituyente no ha desaparecido a la par que el texto constitucional.

5 Desde las primeras reflexiones sobre la Constitución, efectuadas en 1980 por el ya mencionado trabajo de Jiménez Campo («Algunos problemas de interpretación en torno al Título X de la Constitución», Revista de Derecho Político, n. ${ }^{\circ}$ 7, 1980), al más reciente y completo, de gran precisión y brillantez: ALÁEZ CORRAL, B., Los limites materiales a la reforma de la Constitución española de 1978, BOE-CEPC, Madrid, 2000; pasando por otras aportaciones anteriores o posteriores: BALAGUER CALLEJÓN, F., «El «status» constitucional de la reforma y la «fragmentación» del poder constituyente», en La democracia constitucional, Estudios Homenaje a Francisco Rubio Llorente, CEPC, Vol. I, págs. 99 a 130, Madrid, 2002. CONTRERAS, M., «Sobre el Título X de la Constitución Española: de la reforma constitucional», Revista de Derecho Político, n. ${ }^{\circ} 37$ (segundo especial sobre La reforma constitucional), págs. 303-318, 1992. CABO MARTÍN, C. de, La Reforma constitucional en la perspectiva de las Fuentes del Derecho, Trotta, Madrid, 2003. GARCÍA ATANCE Y GARCÍA DE MORA, M.V., «La reforma constitucional y las cláusulas de intangibilidad», Revista de Derecho Político, n. ${ }^{\circ} 37$ (segundo especial sobre La reforma constitucional), págs. 319-330, 1992. o VEGA GARCÍA, P. de, La reforma constitucional y la problemática.. . Entre otros.

6 VEGA GARCÍA, P. de, La reforma constitucional y la problemática.. , págs. 157 y 158, señala, con Jiménez Campo el «agnosticismo» o «indiferentismo» constitucional, que introduce una superlegalidad meramente formal.

7 VEGA GARCÍA, P. de, La reforma constitucional y la problemática.. , pág. 143 y ss. 
cultad de la propia constitución. La reforma es una operación jurídica que no puede convertirse en acto revolucionario. El autor alemán, recuerda que las regulaciones pueden ser sustituidas por otras pero garantizando la identidad y continuidad de la constitución. No se da una nueva Carta, sino que se hacen adiciones, refundiciones, supresiones... ${ }^{8}$. Por otro lado, centrados en la realidad constitucional española, que sea admitida por la Constitución una reforma total, no basta como habilitación hacia el poder de reforma para llevar a cabo una revolución`. Por otra parte Ruipérez, siguiendo a De Vega, justifica los límites materiales a la reforma, en la supremacía de la soberanía popular, del mismo modo que la supremacía normativa de la constitución impone unos límites formales ${ }^{10}$. Recuerda a Hesse al expresar que la existencia de un «núcleo estable», determinado por el poder constituyente, suscita un espacio apartado de la discusión posterior. Por último afirma que la inexistencia de cláusulas de intangibilidad no es motivo suficiente para entender que el Constituyente rechazó la existencia de un «núcleo estable» o irreformable, ya que este puede encontrarse implícito ${ }^{11}$.

\section{UNA DESCRIPCIÓN DE LOS LÍMITES A LA REFORMA.}

Si de lo que se trata es de señalar lo que la Constitución ha callado, la dificultad es manifiesta. Probablemente, el ánimo de adhesión a las tesis que anteceden permiten aventurar algunos preceptos o materias que, de aceptarse finalmente la existencia de estos límites materiales implícitos, serían candidatos a engrosar esa categoría en nuestra Ley de Leyes. Procede, por tanto actuar con cautela para engarzar suficientemente esos hipotéticos límites con la letra constitucional.

Así, a continuación intentaré exponer con cierta sistemática los límites a la reforma constitucional, comenzando con los expresados por el propio texto constitucional (en las normas de reforma, de carácter temporal y formal), y terminando por aquellos que pudieran estar presentes de manera implícita una vez se acepta la naturaleza limitada del poder de reforma. Los primeros se podrían encontrar en el Título X CE, y los segundos se presentarían a lo largo de todo el articulado.

Sobre este punto de partida clasificatorio, ha de aclararse que las normas de reforma (a pesar de su extraordinaria fortaleza derivada de su utilización especializada, que les otorga una consideración trascendental en el panorama de fuentes del derecho) carecen de una capacidad tal que su mera concurrencia permita anular el resto de preceptos constitucionales, una vez entran en juego sus normas del Título X. Así, las prescripciones de procedimiento permiten afrontar un proceso de reforma, pero la Constitución permanece vigente en tanto el proceso se concluye, incorporándose los oportunos cambios. Los valores, derechos o instituciones que estructuran la Constitución continúan desplegando sin excepción su eficacia. Por ello, es fruto de una observación

8 RUIPÉREZ ALAMILLO, J., «Una cuestión actual en la discusión política española:..». Págs. 148 y 149. También en «Estática y dinámica constitucionales en la España de 1978 ...». pág. 235.

9 RUIPÉREZ ALAMILLO, J., «Una cuestión actual en la discusión política española:..». pág. 149. pág. 150: el límite se impone al poder de reforma, al legislador, no a un nuevo poder constituyente.

10 RUIPÉREZ ALAMILLO, J., «Una cuestión actual en la discusión política española:..». pág. 151.

11 RUIPÉREZ ALAMILLO, J., «Una cuestión actual en la discusión política española:..», pág. 152. 
parcial el sostener que los límites a la reforma de todo el texto, sólo pueden ser aquellos meramente formales, y que se encuentran recogidos en el procedimiento de reforma, extrayendo del panorama de interpretación de las normas de reforma, el resto del articulado de la Carta Magna.

\section{Límites a la Reforma fijados en el Título X CE. Un SISTEMA SiN CLÁUSULAS DE INTANGIBILIDAD}

Puede responderse, aunque algunos autores estimen lo contrario, que no existen. Trataremos modestamente de explicarlo: los aparentes límites expresados en el Título X, se sitúan en el art. 169 CE y se refieren simplemente a una prohibición de iniciar el proceso de reforma, cuando España se encuentre en guerra, o haya tenido que ser aplicado el art. $116 \mathrm{CE}$, que posibilita la declaración de los estados de alarma, excepción y sitio. Habría que precisar que lo que el precepto trata no es de limitar la reforma, sino de impedir su comienzo. El art. 169 CE no limita la reforma porque simplemente describe una situación en la que la misma no se efectúa, luego no condiciona sus límites.

También creemos que ajenas a este tema de los límites, se encuentran todas y cada una de las condiciones exigidas por los art. 167 y $168 \mathrm{CE}$ en torno a las mayorías, disoluciones, convocatoria de referéndum, etc., cuya finalidad no es ni delimitar ni dificultar la reforma, sino garantizar que el proceso de cambio se efectúa con sometimiento a la voluntad del constituyente y con respeto a la preeminencia en el sistema de fuentes que ostenta la norma a reformar. Muy en particular hay que referirse a las materias amparadas con mayor tesón, bajo reserva del procedimiento agravado, en el art. 168 CE: su finalidad dista de querer limitar una reforma, siendo su cometido el de levantar un velo de protección adicional sobre las principios e instituciones que el constituyente creyó en su momento como intrínsecas a la configuración de la Carta Magna, utilizando este sistema de garantía, que ciertamente levanta un telón de acero sobre determinados preceptos de la Constitución (pero que se aleja de las cláusulas de intangibilidad conocidas en derecho constitucional comparado) impregnándose el rígido procedimiento de revisión o reforma total, de una posibilidad de cambio $^{12}$, lo que no ocurriría de existir esas cláusulas ${ }^{13}$.

La inexistencia de cláusulas de intangibilidad ha sido unánimemente resaltada y ampliamente criticada. Existen preceptos que declaran la irreformabilidad de alguna de sus instituciones jurídicas, en muchas constituciones de la Unión Europea: Alemania,

$12 \mathrm{El}$ art. $168 \mathrm{CE}$ es un mecanismo de apertura estructural, no es el equivalente a los límites de la reforma. ALÁEZ CORRAL, B., «La reforma constitucional como motor de las transformaciones actuales del Estado español». En Derecho constitucional para el Siglo XXI. Actas del VIII Congreso de Derecho Constitucional.. . pág. 488.

13 Por más que se reitere en muchos estudios un dato cierto: el procedimiento del art. 168 CE tiende a impedir cualquier reforma sobre las materias que protege (Título preliminar, capítulo segundo, sección primera del Título I y Título II), las mismas no llegan a ser imposibles. Simplemente exigen el cumplimiento de la voluntad del constituyente en concitar un elevadísimo grado de consenso, que de concurrir, convierte en factible la reforma, como se demuestra con el planteamiento de la reforma de la Corona, la que más posibilidades de prosperar tuvo desde el planteamiento realizado en 2004, a pesar de ser la única materia que se debía someter sin discusión al procedimiento agravado de reforma. 
Francia, Italia, Grecia, Portugal, Chipre y Chequia. Por ejemplo, en Francia e Italia, la forma republicana es intocable por el poder de reforma. En Alemania, uno de los sistemas más referidos para el estudio de estas cláusulas, se somete a intangibilidad la organización de los «Estados» y la definición como Estado federal, democrático, social y de derecho. También la soberanía popular y la inviolabilidad de los derechos fundamentales.

Es una opción política del constituyente y el mero hecho de que el español prescindiera de ellas, estableciendo simplemente una reserva material, diríamos que de alta protección, sobre diversos principios, valores, derechos e instituciones; hace sospechar que el sistema elude una base inmutable o intocable, careciendo por ello de una estructura de ideología constitucional sólida. Pero esa conclusión es aventurada, porque en realidad lo que pudo suceder en el proceso de elaboración, es que la base social de la decisión constituyente fue tan amplia, que impedía incluso petrificar en el texto instituciones que a pesar de su aceptación unánime o mayoritaria, podrían entonces transmitir distintas connotaciones. Así por ejemplo, asociar como en otros países su forma de Jefatura de Estado, a una cláusula de intangibilidad, hubiera sido someter a una prueba de paciencia y cesión más, a los sectores que estaban dispuestos a convivir en una monarquía parlamentaria, pero sin rehusar su modelo republicano ideal. Esta técnica de protección del art. $168 \mathrm{CE}$ otorga por ello una posibilidad de replanteamiento del modelo, si bien veremos más adelante que puede que no sea otra cosa que «posibilidad», si se acepta que existen límites implícitos a la reforma.

Lo que si parece evidente, más que el enfoque técnico de garantía de los derechos e instituciones superprotegidos en el art. $168 \mathrm{CE}$, es la descuidada delimitación material que se genera en la remisión por bloques de títulos o capítulos. Se junta así la protección de la unidad de España (art. 2 CE) con la necesidad de utilizar una norma de ley orgánica para establecer las bases de la organización militar (art. 8.2 CE), en el Título Preliminar; o el derecho a la vida (art. $15 \mathrm{CE}$ ), con la prohibición de los tribunales de honor (art. 26 $\mathrm{CE}$ ); y el orden sucesorio de la Corona (art. $57 \mathrm{CE}$ ), con el ejercicio regio del Alto Patronazgo de las Reales Academias (art. 62.j CE) ${ }^{14}$.

Que nuestro constituyente desestimara el uso de las cláusulas de intangibilidad, no impide que haya de reconocerse en las mismas una figura de notable interés y utilidad, sobre todo en países socialmente propensos a la revisión periódica de sus bases estructurales. Además, con ello se evitaría la posibilidad de incurrir en errores de interpretación constitucional cuando el operador jurídico ha de indagar en la búsqueda de presuntos límites implícitos para compensar la ausencia de las cláusulas ${ }^{15}$, obteniendo en su caso efectos diversos aquéllos respecto de éstas. Tampoco la presencia del mecanismo de garantía y protección, articulado por el art. $168 \mathrm{CE}$ (que desde luego otorga pistas sobre los

14 CONTRERAS, M., «Sobre el Título X de la Constitución Española:..», pág. 309 y 310: respecto del 168, opina que la voluntad del constituyente fue loable pero su técnica jurídica deplorable. ALÁEZ CORRAL, B., Los límites materiales a la reforma.. págs. 304 y ss., valora positivamente el planteamiento de los arts. 166 y $167 \mathrm{CE}$ como una buena obra de ingeniería constitucional, pero critica las deficiencias de los arts. 168 y 169 CE.

15 Por más que sea pertinente defender, como así nos inclinaríamos a pensar, la existencia de límites constitucionales implícitos, su determinación y ámbito estará sujeto a la interpretación, cuestión que no sucedería con la literalidad de una cláusula de intangibilidad. En torno a esta conveniencia de las cláusulas: CONTRERAS, M.,, «Sobre el Título X de la Constitución Española:..», pág. 311. 
límites implícitos), sirve de sustitutivo a las cláusulas de intangibilidad ${ }^{16}$. Si bien por su rigidez, puede desanimar a iniciar una reforma sobre las materias afectadas, no puede impedirla ${ }^{17}$. Su naturaleza no será nunca la de limitar la reforma de determinados preceptos sino la de establecer para la misma un procedimiento especial. Las materias no se limitan ante la reforma, sólo se protegen. Los límites explícitos o cláusulas de intangibilidad, sirven para fortalecer las decisiones históricas del constituyente, su cometido es el determinar los pilares de la legitimidad constitucional ${ }^{18}$. La materia intangible que para Hauriou marca la superlegalidad constitucional ${ }^{19}$. Como se puede estimar, sólo desde estos puntos de vista cabe desarrollar una teoría en torno a estas cláusulas ${ }^{20}$.

\section{LAS RAZONABLES DUDAS SOBRE LA AUSENCIA DE LÍMITES MATERIALES}

Corresponde ahora indagar sobre los límites constitucionales de fondo, que pudieran interponerse frente a una reforma. Su característica o naturaleza sería la de hallarse implícitos en el texto constitucional, pero sin que su determinación, una vez aceptados, se sujetara a conjeturas en cuanto a su contenido. De concluir su existencia, habrá que referirse a ellos de manera expresa y concreta.

Lo que se puede cuestionar no es tanto la existencia de los preceptos que contienen principios, derechos, valores o garantías institucionales, sino la consideración de los mismos como límites ante una reforma. Por tanto existen preceptos claves, se pueden encontrar en la Constitución, pero habrá que discutir sobre su fuerza en el juego de la reforma. Estas normas jurídicas son bien distintas por naturaleza, a otros presuntos límites vinculantes derivados de «(...) determinadas condiciones lógicas, históricas, metafísicas, ontológicas y, en general, sobrenaturales(...)», cuya concurrencia en nuestro sistema ha de rechazarse ${ }^{21}$.

16 RUIPÉREZ ALAMILLO, J., «Estática y dinámica constitucionales en la España de 1978. Especial referencia a la problemática de los límites a los cambios constitucionales», En La reforma constitucional: la organización territorial del Estado, la Unión Europea y la igualdad de género, ROURA GÓMEZ S. A. y TAJADURA TEJADA, J. (Dirs.), Biblioteca Nueva, págs. 19 a 280, Madrid, 2005. pág. 236, con Bryce y Esposito, recuerda que los procedimientos superagravados equivalen a establecer límites expresos a la reforma. No compartimos del todo la contundencia de esa asociación.

17 PÉREZ ROYO, J., La reforma de la Constitución, Congreso de los Diputados, Madrid, 1987, pág. 190: el art. $168 \mathrm{CE}$ es el que establece los límites a la reforma, sustituyendo las cláusulas de intangibilidad, para proteger los fundamentos del sistema democrático o la forma política del Estado. Al respecto de lo manifestado por este autor, entendemos que la naturaleza de las cláusulas de intangibilidad y las reservas de procedimiento del art. $168 \mathrm{CE}$ es distinta.

18 VEGA GARCÍA, P. de, La reforma constitucional y la problemática.. , pág. 248.

19 VEGA GARCÍA, P. de, La reforma constitucional y la problemática.. , pág. 256.

20 GARCÍA ATANCE Y GARCÍA DE MORA, M.V., «La reforma constitucional y las cláusulas de intangibilidad», Revista de Derecho Político, n. 37 (segundo especial sobre La reforma constitucional), págs. 319-330, 1992 . pág. 321: con De Vega, parte de la limitación del Poder de reforma como constituido. En pág. 325 y 326, esgrime argumentos sobre la naturaleza del poder de reforma como limitado y la superioridad de la norma constitucional respecto de la norma de revisión. Pero la clave, para esta autora, está en que se garantice la subsistencia de supuestos ideológicos y valorativos. Ya en 1992 sugiere añadir cláusulas de intangibilidad sobre el art. 1 CE y el art. 10 CE.

21 Son palabras utilizadas, como es natural para negar este tipo de límites por REQUEJO PAGES, J.L., «Límites constitucionales a la reforma de la Corona», en VV.AA., La reforma constitucional, Ministerio de Justicia (XXVI Jornadas de Estudio de la Abogacía General del Estado, 27, 28 y 29 de octubre de 2004), págs. 455 a 464, Madrid, 2005, pág. 456. 
El art. 16 de la Declaración Universal de Derechos del Hombre de 1789, asociaba la existencia de Constitución a la separación de poderes y la garantía de los derechos ${ }^{22}$. Es un concepto clásico revisable pero que sirve de referencia para describir una constitución democrática y por ello, para descubrir qué es. Así, como punto de partida, parece claro que al margen de lo expresado en las normas de reforma españolas, cualquier cambio que negara, no ya lo que dice una declaración elaborada hace más de dos siglos, sino el concepto de constitución extendido pacíficamente en nuestro entorno occidental, sería imposible. Encontramos ya un límite sustancial y de fondo, aunque abierto e inconcreto: la reforma ha de respetar las bases del concepto de constitución democrática vigentes.

La tradición liberal en el respeto a la separación de poderes y la garantía de los derechos se va transformando en una intervención de los poderes para asegurar esos fines. Para ello utiliza el carácter o la cualidad de la supremacía constitucional, que se logra con la rigidez (incluso en Gran Bretaña). Con ello, la forma acompaña al fondo en una primera caracterización de lo que supone dotarse de una norma constitucional. Superando las reflexiones meramente normativas se ha avanzado en busca de una significación política e histórica, de unos criterios que sean marcados por el principio de soberanía popular, que eviten el Schmittiano intento de que la constitución se convierta en mero instrumento, o en ley en blanco. Aseverar la existencia de los principios y valores que inspiran el ordenamiento constitucional, localizarlos y eximirlos de la revisión impide admitir la revisión total de una constitución, que es lo que podría entenderse literalmente en el art. 168 de la nuestra.

Numerosos son los ejemplos acerca de frenos sustanciales a la reforma total: el más claro y repetido por De Vega es el contenido en el art. 1.2 CE y la atribución de la soberanía al pueblo, que funciona como un claro límite material implícito. Saber que existen es insuficiente, y sin una delimitación expresa, su reconocimiento por el sistema carecería de significado práctico. Aplicar la denominación de «límites implícitos» a preceptos de esta naturaleza, demanda muchas precisiones (distintas tesis: Ehmke, Giacometti), por la pluralidad histórica y política del Estado, y la variedad de los rasgos en cada nación ${ }^{23}$. Estaríamos ante una hipotética categoría de límites (implícitos o expresos en la constitución pero no relacionados formalmente en las normas que tratan la reforma) de carácter particular a cada Estado y que habría de desarrollarse partiendo de cada constitución nacional.

En nuestro país, la mayor parte de quienes han estudiado este tema, coinciden en varios de los preceptos que sostienen esos límites (si bien las categorías y denominaciones no son homogéneas, así como tampoco el proceso para reconocer o justificar su existencia, ni su naturaleza jurídica ${ }^{24}$ ): Por ejemplo Aláez ${ }^{25}$ destaca: los valores del art. 1 CE (los define como «contenido esencial identificativo» de la Constitución española de 1978), precepto que sería intangible directa o indirectamente (por la supresión de ciertos derechos del Título I, capítulo segundo, sección, primera) ${ }^{26}$; la dignidad de la persona (no referida en la

22 VEGA GARCÍA, P. de, La reforma constitucional y la problemática.., pág. 267 y ss.

23 VEGA GARCÍA, P. de, La reforma constitucional y la problemática.. , pág. 289: Orlando en 1890, o Elías Díaz en 1984 siguen señalando la conexión del principio de soberanía con los principios liberales de división de poderes y respeto a los derechos.

24 Muy en especial, en el caso de ALÁEZ CORRAL, B., Los límites materiales a la reforma.. .

25 ALÁEZ CORRAL, B., Los límites materiales a la reforma.. , pág. 408.

26 ALÁEZ CORRAL, B., Los límites materiales a la reforma.. , pág. 409. 
reserva material del art. 168 CE pero incluida por su relación con el Título I, capítulo segundo, sección, primera); o la unidad de la nación española del art. 2 «(..)fundamento previo y externo(...)» de la propia Constitución, dice el autor.

Un precursor de Aláez en hallar límites desde el punto de vista estrictamente normativo y no metajurídico fue, veinte años atrás, Jiménez Campo, que se aproxima a los límites implícitos partiendo de la superioridad de la constitución sobre las normas de reforma en ella contenidas, creyendo más acertada la búsqueda de límites expresos o «textuales», según terminología de Cicconetti ${ }^{27}$. En esta línea, también se pronuncia Con$\operatorname{treras}^{28}$ apuntando como uno de esos límites expresos «textuados», y núcleo irreductible, el art. 10.1 CE o la inviolabilidad de los derechos y libertades. En realidad, solo quienes niegan límites ante la actuación del art. $168 \mathrm{CE}$, dejan de apuntar materias que implícitamente se puedan considerar como tales ${ }^{29}$. García-Atance señala específicamente a los arts. 1 y $10 \mathrm{CE}^{30}$. Y en posteriores trabajos apunta el art. $2 \mathrm{CE}$ y los principios que considera previos o preconstituyentes (derechos inviolables inherentes a la dignidad humana) ${ }^{31}$. Ruipérez los concreta en el principio del Estado social y democrático de Derecho, en la atribución de la soberanía al Pueblo español, la mayoría de derechos fundamentales y libertades, el contenido esencial de los procedimientos de reforma, y las Comunidades Autónomas y sus facultades legislativas. Resalta incluso elementos más concretos derivados de los anteriores: el principio de Autonomía, la conservación de un centro de Poder del Estado y otros autonómicos, la articulación de España como «Estado Federal Social» dice, y la configuración de España como un Estado descentralizado sin derecho a la secesión de sus partes ${ }^{32}$. Balaguer tras volver a recordar que los límites en la constitución se presentan como frenos al poder constituyente-constituido $0^{33}$, no como frenos al poder constituyente, y que sustituyen a las cláusulas de intangibilidad; apunta que el propio proceso de integración europea ${ }^{34}$ limitaría nuestro poder de reforma, de un lado, así como de otro, también constituiría un límite el proceso interno de descentralización. Torres del

27 JIMÉNEZ CAMPO J., «Algunos problemas de interpretación en torno al Título X de la Constitución», Revista de Derecho Político, n 7, 1980, págs. 92 y 93.

28 CONTRERAS, M., «Sobre el Título X de la Constitución Española: ..», pág. 312.

29 Como nos recuerda GARCÍA ATANCE Y GARCÍA DE MORA, M.V., «La reforma constitucional y las cláusulas de intangibilidad», pág. 322 y ss.: Pérez Royo interpreta que la reforma no tiene límites.

30 GARCÍA-ATANCE Y GARCÍA DE MORA, M.V., «La reforma constitucional y las cláusulas de intangibilidad», Revista de Derecho Político, n. ${ }^{\circ} 37$ (segundo especial sobre La reforma constitucional), págs. 319 a 330, 1992, pág. 327, ya que sugiere añadir cláusulas de intangibilidad sobre estos preceptos.

31 GARCÍA-ATANCE Y GARCÍA DE MORA, M.V., reforma y permanencia constitucional, CEPC, Madrid, 2002, pág. 287: artículos 1, 2 CE (la unidad de la nación española), y art. 10 CE (Con De Otto, Contreras y Jiménez Campo).

32 RUIPÉREZ ALAMILLO, J., «Una cuestión actual en la discusión política española:..», pág. 152, citando a Calzada Conde (CALZADA CONDE, R., La reforma constitucional y las mutaciones en el ordenamiento constitucional, Universidad de Salamanca, Salamanca, 1987. Y «Reflexiones en torno a la reforma constitucional», Cuadernos de la Cátedra Fadrique Furió Ceriol n 5, págs. 49 a 67, 1993).

33 BALAGUER CALLEJÓN, F., «El «status» constitucional de la reforma y la «fragmentación» del poder constituyente», pág. 105, en línea con la calificación de la reforma como fruto del poder constituido.

34 BALAGUER CALLEJÓN, F., «El «status» constitucional de la reforma y la «fragmentación» del poder constituyente», pág. 116, la situación institucional de España en el proceso de integración en la Unión Europea, junto con la aplicación del proceso descentralizador desde hace tres décadas, ha provocado mutaciones constitucionales sobre el contenido material de la Constitución, interponiendo, por ejemplo, nuevos límites a la reforma. 
Moral fija como único limite absoluto a la reforma la soberanía del pueblo ${ }^{35}$. Más recientemente, Diez-Picazo analiza el juego de los límites derivados de los compromisos internacionales referidos al poder constituyente, pero extendidos también como límites ante una reforma ${ }^{36}$. El derecho constitucional de los Estados podrá estar desligado de la opinión de la comunidad internacional en base al principio de no intervención, pero esto no supone que para ella sea absolutamente indiferente la configuración constitucional de un país. Asimismo, numerosas facetas de la soberanía estatal evolucionan en un marco de puesta en común de valores, de universalización de derechos, siendo un ejemplo de ello cierta quiebra en el monopolio jurisdiccional de los Estados, fruto del desarrollo de la protección internacional de los derechos humanos ${ }^{37}$. Por último, el propio sistema internacional y convencional de fuentes del derecho, impide a un Estado desconocer sus compromisos firmes bilaterales o multilaterales ${ }^{38}$. Desde esos presupuestos, destaca los derechos humanos como un contenido material de los límites internacionales ante las disposiciones constitucionales nacionales, citando al efecto el contenido vinculante de los convenios internacionales de ámbito regional (Convenio de Roma de 4 de noviembre de 1950 o Convenio Interamericano de Derechos Humanos, de 7 de abril de 1970), así como la labor de los tribunales que han potenciado y garantizado su eficacia ${ }^{39}$. Junto con los derechos humanos, apunta otros contenidos materiales derivados de compromisos internacionales que han limitado la disposición de los países signatarios (por ejemplo, la sujeción a neutralidad permanente de la República de Austria tras el Memorándum de Moscú, de 15 de abril de 1955$)^{40}$. Tras otras consideraciones concluye aseverando la existencia de límites a la reforma basados en los compromisos internacionales, aunque la dificultad de observarlos puede residir en la falta de control jurisdiccional y constitucional ante un proceso de reforma ${ }^{41}$. Con ocasión de un tema tangencial, Tajadura Tejada ha te-

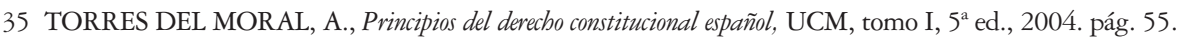

36 DIEZ-PICAZO GIMÉNEZ, L.M., «Límites internacionales al poder constituyente», Revista Española de Derecho Constitucional, $n^{\circ}$ 76, págs. 9 a 32, 2006. En pág. 13, afirma expresamente la existencia de límites internacionales tanto respecto del poder constituyente como del poder de revisión constitucional. La concepción clásica del poder constituyente como originario impediría adjudicarle límite alguno, pero ese concepto entra en crisis, especialmente ante la creación de constituciones de carácter federal, o por la ignorancia del peso de las normas provisionales que regulan los períodos preconstituyentes (pág. 10). Constata el autor la existencia de cierto consenso en admitir los límites impuestos por el derecho internacional ante el poder constituyente, incluso desde los enemigos del concepto «supranacionalidad» (cita a G. Vedel, pág. 11).

37 DIEZ-PICAZO GIMÉNEZ, L.M., «Límites internacionales al poder constituyente», pág. 13.

38 DIEZ-PICAZO GIMÉNEZ, L.M., «Límites internacionales al poder constituyente», págs. 14 y 15 : cita el art. 27 del Convenio de Viena: «Una parte no podrá invocar las disposiciones de su derecho interno como justificación del incumplimiento de un tratado». En el ámbito de los derechos humanos, es especialmente claro que los tratados internacionales limitan las opciones constitucionales de los países que los han suscrito. El autor cuestiona, sin embargo, la eficacia del derecho internacional general, al margen de los tratados interpartes, como límite, si bien constata la existencia de estudios a favor de esa posibilidad.

39 DIEZ-PICAZO GIMÉNEZ, L.M., «Límites internacionales al poder constituyente», págs. 17 y 18.

40 DIEZ-PICAZO GIMÉNEZ, L.M., «Límites internacionales al poder constituyente», pág. 20.

41 «Hay que tener en cuenta que el poder constituyente derivado o de revisión constitucional es, en puridad, un poder constituido, pues es creado y regulado por la constitución misma. Esta somete su ejercicio a un cierto procedimiento y, en su caso, a determinadas limitaciones materiales. Pues bien, una revisión constitucional que vulnerase una de esas limitaciones materiales-entre las que bien podrían figurar determinados compromisos internacionales- sería ciertamente inconstitucional. El problema es que los ordenamientos en que existe, el control jurisdiccional de constitucionalidad suele referirse a leyes, no a la 
nido ocasión de reivindicar la necesidad de cierta resistencia constitucional en línea con García Herrera para llamar la atención sobre la necesidad de defender el sentido de la soberanía estatal y lo que de garantía de ella se deriva, muy en especial ante el acrítico proceso de integración supranacional ${ }^{42}$.

Compartiendo con autores más arriba mencionados la necesidad de contar con los compromisos internacionales, específicamente los referidos a la protección de derechos humanos, como un útil y positivo límite externo, ha de ser necesario, también y al tiempo, salvaguardar la fortaleza de la organización soberana de cada territorio cuando de la misma se deriva un entramado participativo propio de la representación estructurada que no siempre se manifiesta con inmediatez y claridad en ciertas instancias internacionales, o al menos lo hace en un grado representativo o participativo más lejano y menos controlable ${ }^{43}$.

La STC 48/2003, de 12 de marzo, (f.j. $7^{\circ}$ ), con ocasión de la Ley de Partidos Políticos, potenció las opiniones contrarias a la existencia de límites implícitos. Así, entre otros, García Torres ${ }^{44}$, señala que tras esta decisión hay que descartar la existencia de límites materiales absolutos como los defendidos por algunos autores, como por ejemplo García-Atance. La Constitución española, a diferencia de la francesa o la alemana, no excluye de la posibilidad de reformar ninguno de sus preceptos ni somete el poder de revisión constitucional a más límites expresos que los estrictamente formales y de procedimiento. Ciertamente, nuestra Constitución también proclama principios, debidamente acogidos en su articulado, que dan fundamento y razón de ser a sus normas concretas. Son los principios constitucionales, algunos de los cuales se mencionan en los arts. 6 y 9 de la Ley impugnada. Principios todos que vinculan y obligan, como la Constitución entera, a los ciudadanos y a los poderes públicos (art. 9.1 CE), incluso cuando se postule su reforma o revisión y hasta tanto ésta no se verifique con éxito a través de los procedimientos establecido en su Título X. Esto sentado, desde el respeto a esos principios, y como se afirma en la Exposición de Motivos de la Ley recurrida, según acabamos de recordar, cualquier proyecto es compatible con la Constitución, siempre y cuando no se defienda a través de una actividad que vulnere los principios democráticos o los derechos fundamentales. Hasta ese punto es cierta la afirmación de que » (...) la Constitución es un marco de coincidencias suficientemente amplio como para que dentro de él quepan opciones políticas de muy diferente signo» (STC 11/1981, de 8 de abril, FJ 7).

De la lectura de la sentencia hay que concluir que, efectivamente, ante una reforma, se puede proponer todo sin que, en principio, quepa adjudicar a ningún contenido objeto de la reforma el calificativo de «inconstitucional», ante la ausencia de cláusulas de in-

revisión constitucional. La verificación de la regularidad de la revisión constitucional-incluida, allí donde esa posibilidad existe, la aprobación de leyes constitucionales- está normalmente encomendada a órganos políticos; pero, en cuanto ejercicio de un poder constituido, sería concebible su sumisión a control jurisdiccional de constitucionalidad». DIEZ-PICAZO GIMÉNEZ, L.M., «Límites internacionales al poder constituyente», pág. 27.

42 TAJADURA TEJADA, J., «Los principios constitucionales ante el desafío de la globalización». En $D e-$ recho constitucional para el Siglo XXI. Actas del VIII Congreso de Derecho Constitucional.., pág. 250 y ss., en línea con GARCÍA HERRERA, M.A., «Rigidez constitucional y Estado Social», En La experiencia constitucional: del Estado legislativo de derecho al Estado constitucional de Derecho. CGPJ, Madrid, 1999.

43 BELDA PÉREZ-PEDRERO, E., La fallida reforma de la Constitución española durante la VIII Legislatura constitucional (2004-2008), Thomson-Civitas, Madrid, 2008.

44 GARCÍA TORRES, J., «Consideraciones sobre la posible reforma del Derecho dinástico constitucional», pág. 440. En la misma obra, en pág. 456, con parecido sentido se pronuncia Requejo. 
tangibilidad. Pero algo distinto es deducir, a partir de los razonamientos del Tribunal, que de la exigencia de respeto a un procedimiento pacífico para discutir todo, no pueda derivarse precisamente el mínimo garantizado por una constitución democrática: el respeto a las bases del sistema sujeto a reforma ${ }^{45}$. La revisión carece de libertad absoluta, de patente para llevar a término actos revolucionarios ${ }^{46}$.

\section{Preceptos Constitucionales Que PODRÍAN estimarse COMO FUENTE DE LOS HIPOTÉTICOS LÍMITES IMPLÍCITOS}

Cabe preguntarse sobre la repercusión práctica de efectuar una relación de los posibles límites implícitos o expresos-implícitos, desde un punto de vista doctrinal, cuando nuestro propio Tribunal Constitucional evita este terreno, como se puede comprobar, muy posiblemente por considerarlo ajeno a nuestro sistema. Lo que ocurre es que se sugiere, y no solo desde los extremos, si no desde el poder, con ocasión de la reforma del art. 57.1 CE en la VIII Legislatura, afrontar un proceso de reforma en el que se ha de utilizar el procedimiento agravado del art. $168 \mathrm{CE}$, que es el que literalmente permitiría una revisión sin límites. Y ante la opinión del Tribunal en una resolución cuyo objeto principal es otra cuestión, se observa un considerable número de referencias doctrinales, como las que hemos citado, que pudieran demandar alguna atención, siendo además avaladas por la tozudez del propio sistema constitucional y de sus bases jurídicas. Los pronunciamientos del Tribunal Constitucional sobre qué considera límites de fondo a la reforma, no van a poder ser utilizados como fuente para su estructuración por su ausencia explícita en el control de la reforma, por lo cual cabría sólo esperar la concreción de sus opiniones al respecto en el momento en el que se produjera una quiebra procedimental del articulado del Título X CE.

Así, en la práctica, nos encontramos pues, en el incierto territorio de la ponderación que hicieran las sucesivas mayorías parlamentarias y el cuerpo electoral en el referéndum preceptivo, interpretando aquellos extremos de la voluntad de la generación que acordó el pacto fundacional, que son intocables o que no pueden rebasarse sin un proceso revolucionario ${ }^{47}$. Esta solución no puede ser satisfactoria, al margen de su incierto resultado y extrajuridicidad, por la absoluta dependencia que el poder constituyente tendría respecto del de reforma.

Por ello, sí que es pertinente aplaudir esta línea doctrinal de referirse a los límites de fondo que se encontraría el poder de reforma, e intentar enunciarlos. La existencia de estas consideraciones podría actuar con carácter de ilustración ante los sujetos llamados a participar en la reforma, previniendo situaciones extremas en las que una hipotética revisión

45 Con TAJADURA TEJADA, J., «El pacto social como límite a la reforma del acto constitucional», pág. 395: el art. 168 CE no puede consagrar un despropósito.

46 RUIPÉREZ ALAMILLO, J., «Estática y dinámica constitucionales en la España de 1978...», págs. 244 a 246, en pugna doctrinal con Aragón Reyes.

47 En la reforma preiniciada o planteada en la VIII Legislatura constitucional es el mismo poder que anticipa la voluntad de iniciativa, el Ejecutivo, el que en su planteamiento y objetivos, insta una reforma esencialmente limitada. Ello no garantiza el desarrollo posterior ni presupone ninguna consideración del Gobierno acerca de la existencia de límites de fondo, tan sólo su opción por modificar ciertos extremos determinados. 
afectara esas bases sustanciales. Evidentemente que, además, al tratarse la detección de los límites de fondo, de una actividad relativa a las reglas de juego de la reforma, hubiese sido todo un acierto su introducción en el texto constitucional como cláusulas de intangibilidad en las normas de reforma de manera expresa. No fue así y sería ciertamente problemático que la inclusión de cláusulas de intangibilidad pudiera también ser un tema de reforma constitucional. Pero ¿acaso no solventaría el problema que se plantea?

El constituyente estableció un conjunto de valores, principios, derechos e instituciones como elementos esenciales de su obra. Los protegió con una serie de garantías y en concreto, ante la reforma, dispuso de unas materias sobre las que los cambios fueran revestidos de unos especiales requisitos gravosos. No es que se permitiese cualquier cambio por radical que fuera, sino que se supuso que de llegar a esos extremos, probablemente se abriría un nuevo proceso constituyente. Así, el planteamiento de una crisis constitucional por utilización del art. $168 \mathrm{CE}$ se buscaba en un ambiente de normalidad constitucional, de continuidad del pacto constitucional que superaría los cambios por profundos que fuesen, bien entendido que a la luz de todo el articulado constitucional y no solamente a partir de las normas de procedimiento ante una reforma. ¿Constituiría una burla a la voluntad del constituyente que se reiterasen en las normas de procedimiento los valores, principios, derechos e instituciones sobre los que sin el menor atisbo de duda consideró oportuno edificar la Constitución de 1978? Evidentemente no. ¿Cabe por ello que una reforma constitucional realizase esa tarea, relacionando, con el mayor respeto a la literalidad y sentido de los artículos de la Constitución que las tratan, una serie de figuras jurídicas que limitaran la reforma (por ejemplo, evitar ataques a los valores del art. 1 CE? Puede que sí. En este caso se trataría sólo de reafirmar la voluntad del constituyente, salvo que creamos que su ánimo expreso fue la de evitar las cláusulas de intangibilidad en busca de permitir en un futuro cualquier reforma que terminara con el espíritu constitucional, con tal que utilizara el procedimiento adecuado. Es un hecho que los poderes constituidos pueden adaptar a la realidad del momento la imprecisión (puede que incluso justificada en la búsqueda del consenso, como ya se ha dicho) consistente en evitar las cláusulas de intangibilidad, estimando que es preciso fortalecer el sistema constitucional desde la repetición en el Título X, de las materias que por su naturaleza, la Constitución de 1978 esgrime como límites.

Probablemente ante una reforma cuyo objetivo fuese la inclusión de lo que hasta ahora se señala por la doctrina como límites implícitos, sería notablemente complicado alcanzar un consenso suficiente sobre la intangibilidad de preceptos cuya naturaleza de límites implícitos hoy se sospecha, pero que no siempre reunirían el plácet social que condiciona la postura de los poderes constituidos que protagonizan la reforma. Así, sería fácil establecer un precepto que pusiera como freno a cualquier reforma la vulneración de la dignidad del art. 10 CE o de los derechos fundamentales y las libertades públicas del Título I, capítulo segundo, sección primera; pero probablemente no lo será tanto la fijación de un límite basado en la unidad del actual territorio de España. En torno a las instituciones, las discrepancias serían también un hecho, por ejemplo en torno a la Corona. Si se sospechara que su exclusión de la intangibilidad las defenestraba como categorías ajenas a límites implícitos (si es que hoy se acepta que lo sean), continuaría su protección procedimental desde el art. $168 \mathrm{CE}$, pero podría ser finalmente suprimida superando los requisitos del mismo. 
Lo cierto es que en el intento de constitucionalizar expresamente los límites del procedimiento de reforma, más que una imposibilidad de acuerdo o de mayorías, se encontraría un impedimento jurídico formal: la posición constitucional misma de las normas de reforma y su naturaleza, posiblemente irreformable, al tener una finalidad técnico-garantista. Los principios, valores, derechos e instituciones ya están en la Constitución, y es una mera cuestión de aceptar qué es la misma, y cuál es su contenido ideológico, para que resulte suficiente aceptar qué cosas son las más importantes de ella, y sobre las que no se puede aplicar el procedimiento de reforma, si de lo que se trata es de suprimirlas o eliminar su esencia.

Como se comprobará, el ánimo por sugerir límites materiales implícitos se rodea de numerosos obstáculos, hasta en una apuesta por su descubrimiento y transformación en cláusulas de intangibilidad que superen la incertidumbre de su débil naturaleza: Las cláusulas de intangibilidad disponen con mayor claridad la imposibilidad de reformar una institución jurídica, y en su caso las excepciones. Los límites se presentan más abiertos y, no sólo hay que descubrir cuáles son, sino cuál es su contenido. Probablemente el más grave de todos los problemas que conlleva la aceptación de límites implícitos, es su posible falta de eficacia, por lo que estaríamos ante el desesperanzador hecho de la irrelevancia en su constatación y la esterilidad de su estudio. Requejo señala con acierto que de existir «(...) límites positivos, o eventualmente imaginables, coinciden en su condición de límites desprovistos de defensa jurisdiccional frente a la contravención, lo que los convierte por igual en jurídicamente inoperantes» ${ }^{48}$, si bien también recuerda, como ya se ha expuesto más arriba, que ciertos espacios de actuación del poder de reforma que encuentran un límite en los compromisos internacionales de España, por ese mismo camino, son susceptibles del control de tribunales o instancias internacionales a los que nuestro sistema se encuentre sometido, pudiendo entonces quedar garantizadas determinadas materias ${ }^{49}$.

Con todos estos inconvenientes, no faltan, como estamos describiendo, los que se lanzan a la sugerente aventura de apuntar una serie de límites de esta naturaleza. Incluso también a realizar clasificaciones de los mismos, como por ejemplo García-Atance ${ }^{50}$, que señala que los límites a la reforma son de tres tipos: heterónomos (jurídicos, pero ajenos al sistema, por ejemplo los derivados de un tratado o compromiso internacional del Estado), Autónomos (jurídicos, en la propia Constitución, clasifica estos en varias divisiones para describirlos: expresos y tácitos; absolutos y relativos; de contenido y de tiempo) y absolutos (no jurídicos, insuperables) ${ }^{51}$.

Además de reiterar los límites que la doctrina ha mencionado, será preciso explicar cuáles van a ser los criterios de identificación y en su caso (en cada valor, principio derecho o institución), qué aspecto relativo a los mismos alcanza relevancia y sustancialidad como base de la estructura constitucional. Un dato jurídico de la mayor relevancia ante este proceso de detección es la determinación constituyente de preservar ciertas materias de una reforma constitucional ordinaria, para someterlas a requisitos gravosos ante su afectación. Si bien ya nos hemos pronunciado sobre la inconveniencia de denominar como límites a las re-

48 REQUEJO PAGES, J.L., «Límites constitucionales a la reforma de la Corona», pág. 458.

49 REQUEJO PAGES, J.L., «Límites constitucionales a la reforma de la Corona», pág. 457.

50 GARCÍA-ATANCE Y GARCÍA DE MORA, M.V., Reforma y permanencia constitucional..., pág. 173 y ss.

51 GARCÍA-ATANCE Y GARCÍA DE MORA, M.V., Reforma y permanencia constitucional..., pág. 206 y ss., tras un amplio análisis con base en la doctrina italiana. 
servas que efectúa el art. $168 \mathrm{CE}$, por tratarse más bien de garantías reforzadas, habrá que convenir que tras la superprotección de una serie de preceptos constitucionales y de bloques de artículos, el constituyente está aclarando cuáles son los elementos claves del texto constitucional, ya que de lo contrario no los ampararía con mayor empeño.

Este papel informador del art. 168.1 CE conduce la mirada, sin embargo, a la ya criticada técnica de remisión a bloques normativos de contenido heterogéneo. Ello es otra consecuencia normativa más del consenso constitucional y de lo que ya podría calificarse como meditada falta de concreción del constituyente, evitando la consagración formal de ciertas instituciones con una reserva ad hoc que recordara las mutuas cesiones y confiriese a la Carta el necesario valor ideológico que ha de poseer, y que es representado en otros textos europeos por las cláusulas de intangibilidad. El resultado, en cualquier caso, fue que la superprotección, además de alcanzar a estas instituciones jurídicas, extendió su velo a otras muchas, cuyo extraordinario amparo no era tan necesario. Lo que si es cierto es que en los bloques señalados desde el art. 168.1 CE se encuentran esos principios, valores, derechos e instituciones que fundamentan la Constitución española, y que al margen de esos bloques, existiendo figuras esenciales, encuentran casi siempre un referente en los conjuntos de artículos referidos por el art. 168 CE.

Recortado a esos espacios normativos el campo de detección de los límites sustanciales, materiales o de fondo, surge de inmediato la cuestión de si instituciones y principios ajenos a esos ámbitos, podrían ser reformados, y en su caso ser suprimidos (existen múltiples ejemplos: una supresión por el poder de reforma del Tribunal Constitucional, cambiando el Título IX en busca de un modelo difuso de justicia constitucional; la modificación del art. 117.5 CE replanteando el principio de unidad jurisdiccional; o, entre otros muchos ejemplos, la eliminación de la igualdad de derechos y deberes en todo el territorio nacional, del art. 139.1 CE). Una primera respuesta ha de consistir en aceptar que, tras el uso del procedimiento de reforma correspondiente, sería posible una reforma de todos estos preceptos. Pero sería antes conveniente deslindar aquellos aspectos de las instituciones o principios sujetos a una propuesta de reforma, que verdaderamente guardasen una relación estrecha e inescindible con los presuntos límites materiales implícitos. Así, puede que el poder de reforma esté en condiciones de suprimir el Tribunal Constitucional si quedase asegurado un sistema de garantías de los derechos en manos del Poder Judicial, o suprimir la unidad jurisdiccional si se sustituyese por una estructuración territorial completa y racional. Pero en otros casos, por ejemplo en el referido a una hipotética desaparición del art. 139.1 CE, o en una eliminación del principio de solidaridad del art. 158.2 CE, la respuesta es distinta por la más estrecha vinculación con esos presuntos límites materiales ajenos al poder de reforma que identifican la base de la Constitución. En los ejemplos propuestos (arts. 139.1 y 158.2 CE), con la igualdad como valor (art. 1.1CE) como principio (art. 9.2 CE) o como derecho (art. 14 CE), entre otros (también con el valor justicia del art. 1.1 CE).

Es más que constatable que la excepción, a la vista de todos los autores mencionados, la protagonizaría el art. 10.1 CE, excluido del capítulo segundo del Título I CE, cuando se refiere a principios clave en la interpretación de los derechos (como la dignidad de la persona, la inviolabilidad de los derechos inherentes, el desarrollo de la personalidad, el respeto a la ley, y el respeto a los derechos del prójimo). Esta exclusión sólo es apa- 
rente ya que el citado artículo no forma parte de ninguno de los capítulos del Título I CE porque en realidad forma parte de todos: la relación de derechos fundamentales y libertades públicas del capítulo segundo del mencionado Título, se entiende en buena medida gracias a este precepto introductor, que informa sobre las características generales y el uso de todo el sistema de derechos. Es por ello oportuno concluir que cuando el art. 168.1 CE despliega una superprotección material sobre ese capítulo, ésta recae también sobre la cláusula que envuelve todo el Título I, que es el art. 10 CE. Diferente es la respuesta respecto de otras bases del sistema español y que sin duda debieran asumir, de aceptarse tal categoría, la calificación de límites implícitos ante la reforma, como la cláusula general de igualdad del art. 14 CE y las garantías de los derechos del art. 53 CE. Si bien en el primer caso, podría explicarse una llamada a la igualdad como elemento transversal necesario para interpretar el catálogo de derechos de la sección primera de su capítulo, en el segundo de los casos, es evidente que el art. 53 CE se encuentra apartado en el capítulo cuarto del mismo título, con lo que no se beneficia de la superprotección consagrada en el art. 168.1 CE, y con ello impide asociar la categoría de límite material a la reforma sólo con preceptos apuntados en los bloques descritos por el procedimiento de reforma agravado.

Así pues, las pistas del constituyente en las materias limitadoras sustanciales son buenas, pero no siempre concluyentes, como demuestra la exclusión de uno de los artículos imprescindibles del sistema de derechos, el art. $14 \mathrm{CE}$, a no ser que se entendiera que la igualdad como valor y como principio en el Título Preliminar, en los arts. 1.1 y 9.2 CE respectivamente, cubren las expectativas de ese precepto, que por lo tanto podría alterarse o incluso suprimirse. $\mathrm{O}$ ante una revisión del contenido de las garantías de los derechos del art. $53 \mathrm{CE}$, se estimase que las bases de ese sistema residen en el valor justicia del art. 1.1 CE o en los principios de actuación de los poderes públicos del art. $9 \mathrm{CE}^{52}$.

Por lo que se refiere a las materias claramente insustanciales encuadradas en el bloque de artículos contenido en el art. 168.1 CE, también nos ofrecen desde un punto de vista distinto, la necesidad de concluir que la delimitación del constituyente en la protección de materias, carece de una total correlación con lo que deba calificarse en conjunto como límites materiales o de fondo ante una reforma. Determinadas atribuciones formales de la Corona, a partir del art. 62 CE, su régimen de inhabilitación (art. 59.2 CE), utilización de las banderas o la capitalidad del Estado (arts. 4.2 in fine y 5 CE, respectivamente), el trabajo remunerado de los presos (art. 25.2 CE), la prohibición de los Tribunales de Honor (art. 26 CE) o la interdicción de ejercicio colectivo del derecho de petición a las Fuerzas Armadas (art. 29.2 CE), son sólo ejemplos entre numerosas cláusulas superprotegidas, de imposible traslación automática al campo de los limites ante la reforma.

Antes de ensayar una enumeración de estas bases que se esgrimirían como límites ante la reforma, habrá que terminar puntualizando su naturaleza peculiar, y depurando además aquellas notas de su configuración que escapan a la condición de erigirse en pi-

52 Es decir, que ante un cambio en el modelo de régimen de garantías sobre los derechos fundamentales, las bases del sistema que actuarían como límite serían sólo las genéricas llamadas a los poderes públicos de respeto al ordenamiento (art. 9.1 CE), promoción de las condiciones efectivas de libertad e igualdad (art. 9.2 CE) o la interdicción de arbitrariedad (art. 9.3 CE). 
lares del texto constitucional de 1978: la condición de límite a la reforma que haya de atribuirse a determinados derechos, valores, principios o instituciones, carece de la fuerza de transformar a esas figuras en intocables o intangibles ante un proceso de reforma. Por tanto lo que se presenta como freno es el respeto a la sustancia (del valor o principio), al contenido esencial (del derecho o libertad) o a la imagen maestra (de la institución consagrada constitucionalmente). Por ello, el proceso de reforma puede afectar a las figuras jurídicas básicas todo lo que sea necesario para adecuarlas a la realidad, siempre que permanezca reconocible el fondo y objetivo de la misma.

¿Qué figuras (y en qué preceptos) se encuentran en condiciones de presentarse como bases de la estructura de la Constitución española de 1978, para con ello ser considerados como limites materiales ante su propia reforma? Tras reiterar las dudas sobre la virtualidad de esta categoría de límites en España, pero expresando la simpatía por aquellas opciones que los defienden, por su amplio fundamento jurídico, propondríamos como hipotéticos límites los siguientes:

El art. 1.1. CE, que define la España constitucional. Este se presentaría, en su caso, como el más claro e innegable de los límites que oponer ante una reforma contraria a su contenido. Si la utilización del art. $168 \mathrm{CE}$ concluye afectando la esencia de este precepto, parece necesario advertir la finalización de la experiencia constitucional de 1978, ya que en caso contrario el mantenimiento de su denominación y con ello, la presunta continuidad de la voluntad constituyente, serían resultado de una apariencia meramente formal, basada en la estricta observación del procedimiento de reforma pero en la negación de todo el resto del articulado. El poder de reforma está ajeno a transformar lo que se entiende pacíficamente como «Estado social y democrático de derecho», o a suprimir o sustituir el contenido de los valores libertad, justicia, igualdad y pluralismo político. El precepto determina el centro definitorio e ideológico de la Carta Magna y desde él informa sobre el perfil que va a mantener la organización política y las relaciones de convivencia. Ahora bien, las normas de reforma están en condiciones, gracias a (o por culpa de) la posibilidad que estableció el constituyente en el art. $168 \mathrm{CE}$, de afectar todos y cada uno de los extremos que tienen que ver con la configuración del Estado ${ }^{53}$ y los valores propugnados en su organización ${ }^{54}$, incluso ampliar estos con otros nuevos que ar-

53 Así, una futura alteración de las normas del Título VII CE sobre economía y hacienda, que eliminase las llamadas expresas a la planificación estatal (art. $131 \mathrm{CE}$ ), podría afectar a la calificación del Estado como «social», pero puede que no de una forma sustancial, siempre que permanezcan en el texto reformado otras llamadas a la promoción efectiva de los derechos o a la redistribución económica, con lo que la definición constitucional de «Estado social y democrático de derecho», no actuaría como límite material, al quedar a salvo su esencia. Cuestión contraria sería, por ejemplo, el cambio en la configuración de las relaciones entre poderes del Estado, que otorgara al Monarca una capacidad de intervención en la designación de representantes en el Congreso de los Diputados, o una reforma electoral que terminara limitando la participación política. Además de destruir otros valores, estaría rompiendo la base estructural del Estado, rompiendo con su calificación como «social y democrático de derecho».

54 Por ejemplo, el valor del pluralismo exige la posibilidad de toda la ciudadanía de manifestarse políticamente, en sentido amplio, sobre la organización de la sociedad, a través de partidos, sindicatos, medios de comunicación, etc. Pero ello no impide (es decir, no se manifiesta como límite material) que la propia constitución introdujera una disposición en el art. $68 \mathrm{CE}$ mediante la cual se consagrase en el sistema electoral aplicable en el Congreso de los Diputados, la primacía, por cualesquiera medios, de los dos partidos mayoritarios, tras una opción de poder de reforma en este sentido(a través del art. 167 CE o a través del art. 168 CE, si se considera que afecta al valor pluralismo del 1.1 CE). El valor pluralismo político, sólo podría funcionar, a 
monicen con ellos ${ }^{55}$. Tal operación requiere, en efecto, el proceso de reflexión al que obliga el procedimiento agravado. Realizado cualquier cambio sobre el precepto, la voluntad del constituyente permanecerá y por tanto, se habrá ejercitado correctamente el poder de reforma, cuando España siga constituida con el mismo perfil y reuniendo, entre otros posibles valores, los cuatro expresados.

El art. 1.2 CE, consagra la soberanía del pueblo español, que a través de la propia Constitución se manifiesta, «del que emanan los poderes del Estado». Este precepto encierra la singularidad de, por una parte declarar quién es el autor de la norma, y por otra, de recordar al poder de reforma sus limitaciones. Pudiéramos incluso aventurarnos a decir, que de aceptarse la existencia de límites materiales implícitos, este se podría presentar como más explícito que implícito, al poner en evidencia que es sospechosamente fraudulento aprovechar la propia fuerza constitucional para alterar la primacía de su autor, cumpliendo solamente con las formalidades de la reforma: utilizar el sistema para suprimirlo. En este caso, hay que volver a subrayar la compleja presencia del «pueblo soberano» en la vida constitucional, una vez se ha producido su actuación como constituyente, emanando de él los poderes. Su lugar, hasta el momento de elaborar otra constitución, es el de disfrutar de su obra. Su presencia a través de uno de los sujetos o poderes constituidos, el cuerpo electoral, para otorgar periódicamente la representación o, en su caso participar en otras decisiones, incluida la reforma a través de referéndum, es esencialmente limitada, sometida a las reglas que él mismo creó. Así, el pueblo español puede manifestarse en el proceso de reforma (en las elecciones generales o el referéndum preceptivo, en los supuestos del art. $168 \mathrm{CE}$, o en el posible referéndum derivado del procedimiento ordinario del art. $167 \mathrm{CE}$ ) con la finalidad de garantizar la obra que ha creado, como un resorte de vigilancia ante la actuación de sus representantes, pero sin actuar como pueblo creador de la constitución (al margen de la reforma, es claro que lo podría llegar a hacer durante un proceso revolucionario).

El art. 1.3 y el Título II CE. El art. 1.3 CE, cuya mejorable redacción establece la Monarquía parlamentaria como forma política del Estado, aunque más bien se refiera a la forma de la Jefatura del Estado ${ }^{56}$, genera posiblemente las mayores dudas de cuantos pre-

lo sumo, como determinante del procedimiento agravado si se entendiera que el cambio le afecta, pero puede que no como límite material, ya que el pluralismo en esencia seguiría siendo una realidad, tanto fuera del parlamento, como en cada proceso electoral (mientras todos los agentes políticos pudieran presentarse en igualdad de condiciones, art. 23.2 CE, para concurrir a las elecciones, para intentar beneficiarse de la nueva regla aritmética consagrada por la reforma). En general, sobre valores, DIAZ REVORIO, F.J., Valores superiores e interpretación constitucional, CEPC, Madrid, 1997.

55 El Profesor Jiménez de Parga, sostiene en alguna de sus intervenciones públicas, la existencia implícita de otro valor: la paz. Si el poder de reforma lo considerase así, parece evidente que armonizaría en cierto sentido con los ya existentes, afectando al precepto, pero en ningún caso al contenido y vigencia de los otros cuatro valores ya consagrados. Además el constituyente no parece que hubiera sido contrario a tal determinación, según padece deducirse del espíritu constitucional.

56 ARAGÓN REYES, M.,, Dos estudios sobre la monarquía parlamentaria en la Constitución española, Civitas, Madrid, 1990. pág. 104. También en ARAGÓN REYES, M.,, «Monarquía parlamentaria y sanción de las leyes», en Estudios sobre la Constitución española. Homenaje al profesor García de Enterría, coord. Sebastián Martín-Retortillo, Civitas, vol. III, págs. 1941-1960, Madrid, 1991. Únicamente es forma de Gobierno ya que sólo la Monarquía absoluta podría ser forma de Estado. Sin embargo, hoy en día, poco tiene que ver el Rey con las tareas efectivas de Gobierno, por lo que sólo puede ser forma de la Jefatura del Estado. TORRES DEL MORAL, Antonio, «La Monarquía parlamentaria como forma política del Estado español», en La Corona y la Mo- 
ceptos vamos a referir como susceptibles de presentarse como límites materiales ante la reforma (y con ello, hace extensible la duda acerca de la consideración de límite, como base del sistema, a toda la institución monárquica). Por tanto la cuestión sería si puede admitirse una reforma de la Constitución que suprima la monarquía. Si se estima que la redacción del art. 1.3 CE ha querido trascender a la mención de la forma de la Jefatura, para establecer un carácter monárquico de toda la estructura del nuevo Estado democrático, el art. 1.3 CE estaría entre los presuntos límites y una reforma debería mantener esta institución. Es una constante, durante toda la fase de elaboración constitucional, el deseo de la varios grupos y diputados que eran mayoría en las cámaras, de enaltecer formalmente la figura regia y protegerla de cara a la reforma, como demuestra desde luego la referencia en bloque al Título II, por parte del art. 168 CE, a toda la institución. El art. 1.3 CE intenta por ello en su más que cuestionable redacción, ensamblar la monarquía con la forma del Estado, cuando en realidad, como se ha explicado, aquella es tan sólo la forma con la que se presenta la Jefatura del Estado, englobando la forma política este extremo pero también otros aspectos estructurales ${ }^{57}$. Al respecto De Cabo recuerda recientemente que la redacción literal de esta expresión impediría en cualquier caso cambiar monarquía por república ${ }^{58}$.

Esa férrea voluntad del constituyente de crear una constitución monárquica, de aludir a ella en el primer artículo del texto constitucional, unida a la pista valorativa del art.168 CE, de superproteger ante una reforma tanto el Título Preliminar en el que se consagra como forma, así como el Título II, que la desarrolla; parecen en conjunto indicios suficientes para estimar que en las bases de la Constitución de 1978, una institución que no podría desaparecer, es la Corona. La naturaleza de la Jefatura del Estado ha sido tradicionalmente una pieza básica del régimen político de una nación, siendo más que discutible que el poder de reforma pueda ir más allá de su necesaria adaptación temporal, como sucede en la propuesta de 2004 . Y es claro, además, que dejando a salvo la permanencia de la institución, la reforma es necesaria para continuar el largo proceso de racionalización que la monarquía experimenta gracias al constitucionalismo democrático. Es en este extremo donde el contenido del Título II CE se aleja, una vez establecida la naturaleza básica e institucional de la Corona, de una calificación como elemento clave o sustancial del sistema, en buena parte de su articulado. Una constitución democrática es un continuo factor de cuestionamiento público (y, por ello, un motor de reformas) sobre

narquía parlamentaria en la Constitución de 1978, dir. Pablo Lucas Verdú, Facultad de Derecho, págs. 39 a 84, Madrid, 1983.

57 Monarquía Parlamentaria es, como concepto jurídico, la forma de gobierno. Sólo como símbolo político puede ser la denominada por el art. 1.3 CE forma política del Estado Español. Por tanto, ni en el sentido de organización territorial de poder, ni en cuanto al modo de producir el derecho (clasificación Kelseniana democracia o autocracia), ni tampoco dentro de la división de formas de Estado de Biscaretti (democracia clásica, formas socialistas y formas autoritarias); tiene lógica hablar de la Monarquía Parlamentaria como forma política del Estado. Determinar el soberano es determinar la forma de Estado. La forma de Estado explica como está distribuido el poder en cuanto a elemento constitutivo del mismo (poder soberano) y la forma de gobierno como se organiza el poder en cuanto elemento constituido del Estado (el poder del gobierno). Nuestra Monarquía actual es »forma de Gobierno» ya que la propia Constitución dice que la soberanía reside en el pueblo. Así, se ha pretendido integrar sistemáticamente varios términos: forma de Estado, forma de Gobierno y sistema de Gobierno, con la finalidad de conseguir una calificación genérica y englobadora.

58 CABO MARTÍN, C. de, «Constitución y reforma», En Constitución y democracia, Miguel Ángel García Herrera (coord.), UPV-CEPC, págs. 635 a 651, Zarautz (Guipúzcoa), 2005. Págs. 646 y 647. 
instituciones jurídicas comúnmente aceptadas que se someten temporalmente a un reciclaje de racionalidad. Por ejemplo, las previsiones constitucionales de remoción de obstáculos para la efectividad de los derechos, o las acciones de discriminación positiva de base constitucional, han sido capaces de reformar a nivel constitucional y legal, figuras jurídicas centenarias que, aceptadas por las constituciones democráticas, adquirían nuevo significado, como la propiedad privada o la herencia. En el caso de las instituciones jurídico-públicas, como la Corona, este proceso ha sido más evidente, y en el modelo español, las previsiones del Título II CE muestran una monarquía ampliamente depurada a la luz de las exigencias del constitucionalismo democrático.

Ello no quiere decir que en su contenido, pervivan aún, como muestra la aparcada propuesta de reforma del art. 57.1 CE, resquicios explicables pero inasumibles, que llaman a la actuación del poder de reforma, siendo el de la postergación femenina ante la sucesión, uno de ellos. Pero también, el resto del articulado puede quedar abierto a esa percepción de la reforma, sin que aparezca a lo largo de todo el contenido del Título, un precepto destacable sin cuya redacción actual, la monarquía constitucional como institución que limita la reforma perdiera su contenido. Dicho esto, y por tanto siendo susceptibles de reforma, una vez superado el complejo proceso agravado, elementos tan importantes como la inviolabilidad, la irresponsabilidad ${ }^{59}$, el refrendo ${ }^{60}$, el orden de sucesión y su régimen ${ }^{61}$, el principado ${ }^{62}$, las abdicaciones y renuncias ${ }^{63}$, el consorte del Jefe del Estado ${ }^{64}$, la familia real ${ }^{65}$, la regencia ${ }^{66}$, la tutela regia ${ }^{67}$, el juramento real ${ }^{68}$, la casa del Rey ${ }^{69}$, y todas sus funciones constitucionales ${ }^{70}$ con su correspondiente conteni$\mathrm{do}^{71}$; habrá no obstante que precisar la necesidad de mantener en conjunto las notas esenciales del papel constitucional de la monarquía. Así, la función del Rey en la actualidad, su figura, y por lo tanto, el contenido de esta institución básica para el constituyente, demanda probablemente la concurrencia de buena parte de estas notas, aunque no deban de ser exactamente las actuales, o su configuración deba de permanecer intocable.

Puede por ello hablarse de elementos que, en el Título II CE, acompañan de manera inseparable la figura del monarca, y sin cuya concurrencia, la Corona establecida en 1978 (que representa la monarquía racionalizada compatible con, y al servicio de, un Estado democrático) perdería su significado: a) el simbolismo, el arbitrio y la moderación, esenciales en una magistratura de esta naturaleza, que pueden permanecer aunque sin necesidad de tener un contenido apuntado en ciertos extremos del art. $62 \mathrm{CE}$, por lo que no habrían de considerarse límites las atribuciones regias regladas por el mismo. b) El orden

59 Art. 56.3 CE.

60 Art. 64 CE.

61 Art. 57 CE.

62 Arts. 57.2 y $61.2 \mathrm{CE}$.

63 Art. 57.5 CE.

64 Arts. 58, 59 y $60 \mathrm{CE}$.

65 Arts. 57 a 60 CE y 65 CE.

66 Art. 59 CE.

67 Art. $60 \mathrm{CE}$.

68 Art. 61.1 CE.

69 Art. 65 CE.

70 Art. 56.1 CE.

71 Art. 62 CE. 
sucesorio típico de esta forma de Jefatura de Estado, si bien no tiene que acompañarse este elemento de una concreta determinación sucesoria, que puede ser alterada por el poder de reforma, así como el régimen jurídico de las figuras tradicionalmente asociadas al mismo (regencia y principado). c) La representación exterior del Estado, por razones derivadas de los Convenios y Tratados Internacionales que asignan a los Jefes de Estado y a sus actos, determinadas consecuencias, con lo que las atribuciones regladas nacidas a partir del art. 63 CE, sobre legación activa y pasiva, así como declaraciones de guerra y paz, van aparejadas a la opción constitucional por esta forma de representación de la unidad del Estado. En este caso, se generaría un límite similar al mencionado por algunos autores, como Diez-Picazo ${ }^{72}$ o Balaguer ${ }^{73}$, respecto del papel de freno a cualquier reforma que representan los tratados internacionales, supranacionales, y los espacios de soberanía ya cedidos a las instituciones comunes. d) El refrendo es, según nuestro modesto parecer, el último elemento anexo a la configuración constitucional de la Corona como pilar básico de la Carta Magna, cuya sustancia y efectos habrían de ser considerados un límite, de manera inseparable con la figura regia, aunque pueda alterarse el modo de ejercicio del mismo. Así, la cobertura de otros sujetos sobre la figura simbólica e integradora de actos, cuyo contenido le resulta ajeno al Rey, se presenta como una clave del resultado del proceso histórico de desapoderamiento del monarca, hasta privarle casi por completo de cualquier potestad o capacidad de disposición sobre los asuntos de Estado. Respecto de esta figura, su esencia a respetar ante un hipotético cambio quedaría reducida a la necesidad de que la práctica totalidad de actos públicos del Monarca se refrendasen, quedando fuera del terreno de intangibilidad, quiénes lo refrendan, la responsabilidad del refrendante o los casos excluidos de manera excepcional de refrendo ${ }^{74}$. La esencia del refrendo en nuestro marco constitucional como garantía de la primacía democrática sobre el principio monárquico, es destacada por Requejo con estas palabras: el refrendo sirve para hacer «(...) de la española una verdadera Monarquía republicana, acaso la única enteramente compatible con la democracia constitucional.» ${ }^{75}$.

Serían objeto de una hipotética reforma, el resto de figuras mencionadas por el Título II, siempre que su modificación o supresión, parcial o en bloque, no impidiese el normal desarrollo institucional de la Jefatura del Estado monárquica, afectando en ese caso a su imagen maestra o contenido intrínseco a la institución.

El art. 2 CE es la base constitucional del modelo territorial del Estado. Uno de los preceptos que mayor nivel de atención ha suscitado por la doctrina ${ }^{76}$, y referencia obli-

72 DIEZ-PICAZO GIMÉNEZ, L.M., «Límites internacionales al poder constituyente», Revista Española de Derecho Constitucional, ${ }^{\circ} 76$, págs. 9 a 32,

73 BALAGUER CALLEJÓN, F., «El «status» constitucional de la reforma y la «fragmentación» del poder constituyente», pág. 116.

74 Esa es la tónica de nuestra Constitución y del derecho comparado. En España, sólo se habilita al Monarca para una actuación en solitario en el art. 65.2 CE cuando señala que el Rey nombra y releva libremente a los miembros de la Casa Real, y aún en esa circunstancia, pudiera discutirse que el refrendo se impidiera, sobre todo tratándose de cargos que, aunque de confianza, realizan funciones claves de enlace con el Gobierno.

75 REQUEJO PAGES, J.L., «Límites constitucionales a la reforma de la Corona», pág. 461. La constatación de los caracteres de la monarquía actual y la práctica desaparición del margen de actuación relevante de la Corona en BELDA PÉREZ-PEDRERO, E., El poder del Rey. Alcance constitucional efectivo de las atribuciones de la Corona. Senado, Madrid, 2003.

76 Aunque como es conocido, al hilo del estudio del Título VIII CE. 
gada en el análisis de los problemas y propuestas de reforma, del Título VIII CE. Consagra la «indisoluble unidad de la Nación española», con el reconocimiento y garantía de las nacionalidades que la integran a disfrutar de autonomía. Es ajeno al objetivo de este trabajo un análisis de la convivencia de los principios de unidad y autonomía en el desarrollo constitucional de las últimas décadas, pero cabe ciertamente concluir, al menos que: primero, el art. $2 \mathrm{CE}$ es la llave para desarrollar e interpretar la organización territorial de España; segundo, su posición relevante en la sistemática constitucional, acompañando la definición del modelo de Estado y los rasgos constitucionales, lo sitúan en un lugar principal en las inquietudes y decisiones del poder constituyente; y tercero, que su adscripción al Título preliminar con la correspondiente cobertura de superprotección ante una reforma, añade un indicio más a su categoría constitucional. Por ello, el art. 2 CE debiera actuar, de admitirse la existencia de límites a la reforma, como uno de ellos.

La propia fuerza normativa del texto constitucional se consagra en el art. 9.1 CE, que sujeta a los ciudadanos y los poderes públicos a su cumplimiento. Este precepto se presenta como una razón más de la lectura restringida del art. $168 \mathrm{CE}$ si es que no se quiere admitir el fraude consistente en alterar o suprimir este precepto para finalizar con todo el sistema de garantías, permitiendo actuaciones públicas y relaciones jurídicas al margen de la norma fundamental. Sin este artículo, la Constitución de 1978 deja de existir. Su respeto ha de ser necesariamente un límite hasta para los más reticentes ante la aceptación de esta categoría. La enumeración constitucional de los principios de su sistema jurídico, en el art. 9.3 complementa la cláusula normativa de superioridad del art. 9.1 CE, y acompaña la efectividad de los derechos y libertades: legalidad, jerarquía normativa, publicidad de las normas, irretroactividad de las disposiciones sancionadoras no favorables o restrictivas de derechos individuales, seguridad jurídica, responsabilidad e interdicción de la arbitrariedad de los poderes públicos; son garantías del ordenamiento jurídico inseparables de cualquier constitución democrática, siendo natural que pueda sospecharse de todas ellas una naturaleza limitadora ante la reforma.

El art. 9.2 CE se presenta como el desarrollo de la definición constitucional del art. 1.1 CE, al explicar los caracteres del Estado social y democrático de derecho: la necesaria actitud positiva y el compromiso de los agentes públicos en la consecución de las finalidades que encierran los valores y los derechos constitucionales, frente a la pasividad autocomplaciente del superado Estado liberal. Entre las preceptos destacados como posibles límites, este se presentaría como el más accesorio si se considerase que el contenido aceptado para la expresión «Estado social y democrático de derecho», del art. 1.1 CE, se corresponde, entre otros extremos posibles, con la ejecución del mandato de este precepto: promoción de libertad e igualdad individual y colectiva, efectividad de las mismas, remoción de los obstáculos que las dificulten y promoción de la participación en sentido amplio. De esta forma, sería un complemento o explicación del primer artículo de nuestra Constitución, actuando en su caso de límite en la medida que lo fuera aquél.

$\mathrm{El}$ art. 10.1 CE ha sido destacado por la jurisprudencia y la doctrina ${ }^{77}$, como acompañamiento natural de los derechos y libertades sustanciales, presentándose también en la

77 Pueden ser ejemplo de ello: ALEGRE MARTÍNEZ, M.A., La dignidad de la persona como fundamento del ordenamiento constitucional español. Universidad de León, León, 1996. FERNÁNDEZ SEGADO, F., «Dignidad 
sistemática constitucional como prioridad del Título Primero, acompañando a los cinco capítulos que lo componen pero sin integrar ninguno. Su valor de interpretación, su calidad de cláusula de operatividad, sitúan a la dignidad de la persona y al libre desarrollo de la personalidad (que se consigue a través del respeto a los derechos inherentes e inviolables), en instituciones jurídicas unidas o comprensivas de los derechos fundamentales de la Constitución. El art. 10.1 in fine y 2 CE, también marcan las claves imprescindibles para entender el funcionamiento de los derechos y libertades: respeto a la ley, respeto a los derechos del prójimo, y concepción del significado de los mismos con pretensión de generalidad o universalidad, que impida que se desvirtúen por una visión localista o estatalista.

Los derechos fundamentales y libertades públicas del capítulo II del Título I CE son los últimos candidatos a límites materiales que propondríamos, de aceptarse la viabilidad de esta categoría. La distinción entre cada uno de ellos y su naturaleza abierta a la interpretación y al desarrollo legislativo, demandan que se circunscriba su papel como hipotéticos límites. Parece oportuno destacar que lo que de ellos se pudiera entender como freno a la reforma sería su existencia y los elementos que constituyen su contenido esencial, ya que el legislador orgánico puede regular el resto de su contorno. La habilitación hacia el poder de reforma articulado en el art. $168 \mathrm{CE}$ que suprimiera los derechos fundamentales y libertades públicas o desnaturalizara su contenido esencial, además de por las razones derivadas de la propia Carta Magna de 1978 y el juego de otros preceptos como el art. 1.1 CE, sería incomprensible a todas luces: en esta parcela se presentan con mayor fuerza limitadora que en otros casos, los compromisos internacionales suscritos por España ante Naciones Unidas, el Consejo de Europa o la Unión Europea, que tendrían que ser modificados. ¿Cabría seguir hablando de una Constitución española de 1978, reformada «constitucionalmente», que renunciara a la homologación internacional en el campo de los derechos y libertades? ¿Es oportuno entender entonces, sin buscar límites materiales ajenos al Título de la reforma, que el constituyente se equivocó al desestimar las cláusulas de intangibilidad, y que por tanto, el poder de reforma es materialmente ilimitado? Nuevamente, otro conjunto de materias apunta en dirección contraria.

\section{Materias CONCORDANTES PERO REFORMABLES}

Una vez que hemos referido varios preceptos del Título Preliminar y del Título Primero como posibles límites materiales ante una reforma, habríamos de aclarar cuál es el criterio utilizado en la determinación de unos artículos frente a otros del mismo Título en esta posible categoría. Como se ha comentado, la mención de todo un bloque de artículos por el art. $168 \mathrm{CE}$ es un factor a considerar, entre otros muchos, para determinar las materias que en su día parecieron al constituyente como básicas, en la estructura constitucional. Pero lo cierto es que las razones para destacar los arts. 1, 2 y 9 frente al resto del Título Preliminar, son las derivadas del contenido de cada uno de ellos. Si bien se puede

de la persona, orden valorativo y derechos fundamentales en la Constitución Española de 1978», en XXV Jornadas chilenas de Derecho Público, VV.AA. págs. 11 a 50, 1995. PECES-BARBA MARTÍNEZ, G., La dignidad de la persona desde la filosofía del derecho, Dykinson, Madrid, 2002. TORRES DEL MORAL, A., «Valores y principios constitucionales: Preámbulo, preceptos del título preliminar y artículo 10.1», Revista de Derecho Político, $\mathrm{n}^{\circ} 36$, págs. 17 a 26, 1992. 
comprender que un cambio en la bandera mediante la modificación de art. $4 \mathrm{CE}$, siendo un elemento simbólico de primer orden, dejaría intacto el armazón jurídico y político de la obra del constituyente, puede que una hipotética reforma de los arts. 6 y 7 CE, que consagran los partidos y los sindicatos, respectivamente, suscitara la pregunta acerca de la exclusión de esas cláusulas como límites en razón de su materia. Cierto es que el sistema actual no se entendería sin las garantías que giran en torno a los partidos y sindicatos como instituciones constitucionales, pero el poder de reforma podría modificar elementos sustanciales de estas figuras manteniendo las notas claves de su permanencia, lo cual se deriva ya de otros posibles límites materiales: los valores pluralismo político y libertad, del art. 1.1. CE o los derechos fundamentales consagrados en los arts. 23 y $28 \mathrm{CE}$.

Asimismo habría de justificarse la posibilidad de alterar los órganos constitucionales básicos del funcionamiento constitucional: el Gobierno, Las Cortes Generales, El Poder Judicial, las instituciones autonómicas y locales y el Tribunal Constitucional. Extender la categoría de límites ante una reforma a esas figuras sería tanto como negar la posibilidad de modificaciones. Según se ha dicho con anterioridad, de lo que se trata es que las funciones esenciales que desempeñan esos órganos se cumplieran ante una nueva redacción, de tal modo que se garantizara la eficacia que persiguen los preceptos que sí parecen presentarse como límites materiales: ¿Cómo se entiende el derecho a la libertad sin un órgano que tenga atribuidas facultades ejecutivas, entre ellas, la dirección de cuerpos y fuerzas de seguridad, que protejan ese derecho? ¿Cómo se hace efectivo cualquier derecho fundamental de configuración legal, sin la existencia de un órgano legislativo de alcance general para todo el Estado? ¿Cómo se garantiza la tutela judicial efectiva sin la concurrencia de unos órganos judiciales? ¿Qué virtualidad tendría el principio de autonomía del art. 2 CE si se suprimen las instituciones descritas en el Título VIII ${ }^{78}$. Así pues, las garantías de permanencia de ciertas instituciones sujetas a una reforma, pudieran deducirse de esos preceptos básicos y estructurales descritos como presuntos límites materiales.

Por último me refiero a una cuestión relativa a fuentes del derecho, en concreto sobre los límites de actuación del procedimiento de reforma como es el hecho de negar la reforma destinada a cambiar sus propias normas. ¿Sería ello una limitación de carácter implícito? En realidad, parece evidente que cualquier modificación del procedimiento de reforma para permitir una mayor o menor dificultad en proceder a la misma, supone un fraude constitucional. Las normas de reforma, como más adelante veremos, tienen una naturaleza instrumental pero se acompañan de una fortaleza adicional en tanto se convierten en la garantía de toda la norma constitucional. Y cuando además recogen protecciones especiales para una serie de materias, son el muro de contención único entre las bases esenciales apuntadas por el constituyente y la voluntad de cambio de los poderes constituidos. Por tanto, hay que estimar que el propio Título X CE, actúa como límite implícito-expreso ante la reforma, más que en razón a proteger la materia que trata, desnuda de carga ideológica y valorativa, para preservar el mecanismo de garantía del que se benefician las bases del Estado constitucional.

No obstante, se ha discutido sobre la posibilidad de utilizar uno de los procedimientos de reforma para modificar el otro. Casi nadie ha sostenido la posible utilización

78 CONTRERAS, M., «Sobre el Título X de la constitución Española:..». pág. 310: ya en 1992, afirma que sin alterar el art. 2 CE se podría cambiar el Título VIII hasta acabar con la forma de Estado. 
del art. $167 \mathrm{CE}$ para alterar el art. $168 \mathrm{CE}^{79}$ y con ello suprimir la superrigidez constitucional referida a las materias protegidas ${ }^{80}$, pero se ha apuntado el uso de la revisión o reforma total de la Constitución, del art. 168, para admitir un posible cambio de toda ella, del procedimiento ordinario del art. $167 \mathrm{CE}$ y del referido por el art. $168 \mathrm{CE}^{81}$. La cuestión exige una respuesta reflexiva, de nuevo en torno a las pretensiones del constituyente cuando admite una revisión total. Debiendo de concluirse que admitir cualquier autoaplicación de las normas de reforma sobre si mismas, supone eliminar, agravar o alterar las garantías que protegen los límites, que es como decir las bases del sistema. ${ }^{82}$. La reforma tiene como parte de su naturaleza una función de garantía, separando la norma de reforma (dentro de la constitución), de la ordinaria, haciéndola superior y sometiendo al resto del ordenamiento. Se evita así que el poder constituido se transforme en constituyente $^{83}$. El Título X CE, tanto como marcar el procedimiento de reforma, u obligar a él, pretende proteger la Constitución ${ }^{84}$. Estas normas de reforma o normas procedimentales «límites implícitos formales» ${ }^{85}$, serían las, que actuarían como auténticas cláusulas de intangibilidad implícitas ${ }^{86}$. De Vega, recuerda el caso alemán y la opinión de Ehmke sobre la necesidad de excluir las mayorías de la Ley Fundamental de Bonn exigidas ante una revisión, de su propia reforma. A partir de Merkl y Ross va aportando más justificaciones a la irreformabilidad de las cláusulas de procedimiento: para derogar una norma hace falta otra superior que lo permita. Así, cuando se trata de la «Grundnorm», o bien no se puede justificar un cambio, o bien han de extraerse del propio ordenamiento constitucional preceptos que lo justifiquen.

También, con relación a los aspectos técnicos, se ha alertado sobre la necesidad de conjugar el resultado de la reforma con los preceptos que en ella permanecen, para que el

79 GARCÍA-ATANCE Y GARCÍA DE MORA, M.V., reforma y permanencia constitucional.., págs. 284 y ss. Reitera los límites a la reforma, profundizando en un repaso doctrinal. Advierte de uno que es previo, sobrentendido, e implícito: no poder utilizar el art. 167 CE (sigue a De Vega, De Otto, Alzaga, Sánchez Ferriz y Santaolalla).

80 La doctrina es unánime, por todos, ALÁEZ CORRAL, B., Los límites materiales a la reforma. ., pág. 407: el art. 167 CE no puede alterar las normas de reforma de su propio Título X, ya que los contenidos del 168 CE (muy en particular los principios estructurales y los derechos fundamentales) se verían afectados como consecuencia de una alteración de los órganos y procedimientos previstos para la reforma en ese mismo Título.

81 CONTRERAS, M., «Sobre el Título X de la Constitución Española:..», pág. 314 y 315: Recuerda a De Otto, al señalar que no se puede utilizar el Título X CE para cambiar el propio procedimiento de reforma, salvo cambiar el art. $167 \mathrm{CE}$ utilizando el art. $168 \mathrm{CE}$, o bien este mismo precepto para alterarse a sí mismo. En esa línea RUIPÉREZ ALAMILLO, J., «Estática y dinámica constitucionales en la España de 1978...», pág. 200 y ss.

82 De la misma manera que se sostiene la imposibilidad de una reforma del propio artículo 168 para aliviar la protección determinada en su día sobre ciertos preceptos, habrá que rechazar en el mismo, o a través de un agravamiento del art. $167 \mathrm{CE}$, que se altere la voluntad del constituyente al supervalorar instituciones o principios que en su día fueron relevantes ante el pacto fundacional pero sin llegar a la condición de erigirse en bases del sistema. (Por ejemplo, una reforma del art. $168 \mathrm{CE}$ ampliando materias sujetas al procedimiento agravado, o la elevación de mayorías las parlamentarias exigidas por el art. 167 CE.).

83 VEGA GARCÍA, P. de, La reforma constitucional y la problemática.. , pág. 67 y ss.

84 GONZÁLEZ ENCINAR, Juan José, «La Constitución y su reforma».., pág. 367. las normas de reforma constitucional no son leyes sino Constitución. CABO MARTÍN, C. de, La reforma constitucional en la perspectiva de las Fuentes del Derecho.., pág. 67.

85 VEGA GARCÍA, P. de, La reforma constitucional y la problemática.., pág. 274 y ss.

86 VEGA GARCÍA, P. de, La reforma constitucional y la problemática.., pág. 277: Ehmke, en 1953 subraya el blindaje de la mayoría de dos tercios en el texto de la Ley Fundamental de Bonn, como cláusula excluida de revisión o reforma. 
resultado sea armónico en aras de mantener la racionalidad y congruencia del siste$\mathrm{ma}^{87}$. La obviedad de esta afirmación, encierra en cualquier caso, un nuevo argumento para sostener la capacidad limitada del poder de reforma, que ha de tener presente la estructura preexistente que obliga a indagar (para concordar) en toda su extensión, los extremos de la reforma, para evitar disposiciones constitucionales contrapuestas que, en caso de colisión, llegarían a tener la misma fuerza jurídica.

Recapitulando: las líneas anteriores muestran nuestra modesta opinión sobre la pertinencia de contemplar materias que limiten la reforma. La repercusiones prácticas de ignorar en España la existencia de límites implícitos son bien claras: el constituyente habría habilitado en el art. $168 \mathrm{CE}$ a las mayorías cualificadas y al cuerpo electoral, como poderes constituidos, a terminar con la Constitución de 1978, evitando la apertura de un nuevo proceso revolucionario constituyente gracias a la utilización del procedimiento de 1978, ofreciendo entonces una cobertura constitucional continua al Estado, desde esa Constitución, para darse la apariencia oportuna en cada momento, con respeto a las formas. Esta visión primaría los aspectos meramente procedimentales, olvidando que si los cambios experimentados no concuerdan en líneas generales con la voluntad constituyente de 1978, de lo que se está hablando es de una constitución distinta y el proceso de reforma es un proceso de revolución y conformación de un nuevo constituyente. Recordemos, en cualquier caso, los peligros latentes de buscar una cobertura formal sin sustento ideológico y lo que ello significa para las bases que inspiraron la constitución reformada: el fraude constitucional ${ }^{88}$.

$$
* * *
$$

TitLE: Limits of Constitutional Reform and Revolutionary Proposals

ABSTRACT: When facing a reform, the Spanish Constitution of 1978 has not laid down any limits. However, if one takes into account its nature and contents, it could be argued that substantial and radical reform proposals might be blocked by means of hypothetical implicit limitations.

RESUMEN: La Constitución de 1978 carece de cláusulas de intangibilidad ante una reforma. Sin embargo por su propia naturaleza y desde otros indicios extraídos de su propio articulado, podría sustentarse que determinadas propuestas de reforma, sustanciales y radicales, pudieran verse frenadas por unos bipotéticos límites implícitos.

KeY WORDS: Constitutional reform. Reform limits. 1978 Spanish Constitution. Spain

Palabras Clave: Reforma constitucional. Limites. Constitución de 1978. España

FECHA DE RECEPCIÓN: 17.01.2012 FECHA DE ACEPTACIÓN: 15.02.2012

87 Por ejemplo, CONTRERAS, M., «Sobre el Título X de la Constitución Española:..». pág. 312: lo que cambia, no ha de estar en contradicción con lo que queda.

88 VEGA GARCÍA, P. de, La reforma constitucional y la problemática.. , pág. 291 y ss., figura de la doctrina francesa: trasgresión, o en algunos casos, mutación, utilizando la reforma y sin romper la legalidad, para cambiar el régimen político. 
